\title{
Standing for Mana
}

\section{Executive Summary}

1 There is a North-South difference in the Maori seats. Why is this and how can we counteract it?

2 There is a Left vote in the Maori seats but it is sometimes going to Labour and not to Mana. How will Mana divert that Left vote so that it consistently flows Mana's way? How did Mana miss out almost altogether on the Left vote in the General seats where no candidate went through the threshold of 1000 votes even in electorates where there were significant numbers of workers from Unite and other unions?

3 In the General seats there are several urban seats where the candidate vote and the party vote, even when there was no candidate, was higher than elsewhere. These seats include Wellington Central, Auckland Central, Dunedin North and Whangarei. How can Mana best develop the vote in these seats?

4 The formation of the List requires special attention with a view to assessing capacities for gaining votes, getting media attention and other strengths. How can Mana best organize its List?

5 There is a large range in the Mana vote with Hone having a lot of votes and some candidates not having many. How does Mana convert that range into strength?

6 One way forward might be a set of cluster groups, one for each of the following voter numbers; 0-100, 100-500, 5002000, 2000-7500 and above 7500. The goal for each cluster group of electorates would be to move up to the next level. Each cluster group represents a niche in the range of Mana voters. How do we grow the vote in each particular niche? 
By using questionnaires and developing cluster groups in other ways we could ready ourselves for any by-election that might happen.

The cluster groups might also function as bridges from the Maori to the General seats if that were seen as desirable.

7 Policy cluster groups might also be set up. There is a strong need to have a coherent policy on the use of social media so that we are translating activity on Facebook, Twitter and elsewhere on the net into votes.

8 The face or faces of Mana might now be reviewed with the idea of getting a clear image to develop over a three year period.

9 Research objectives might now be reviewed to be in step with positions where Hone has an edge. For example, Hone's position on smoking could be backed up with state of the art research so we are news makers in that area. In this way we move to active mode rather than passively reacting to things as is so often the case in opposition.

There is also a strong need to conduct polls amongst Maori asking what they want. Once we know this we will have part of the answer on why they are not coming out to vote. The same thing might apply to low paid workers across the board.

10 As well as the above the usual suspects need to be rounded up; fundraising, party memberships, presence at media events and so on all need attention now.

\section{Background}

I came into the Mana Party in the most peculiar way.

For many years I had been following the career of parliamentarians Hone Harawira, Te Ururoa Flavell and Shane Jones, all students at St Stephens while I was teaching there in the early 1970s. As one does. From a distance.

With some concern I heard of a rift in 2009 between Hone and Te Ururoa along with others from the Maori Party. Before 
too long Hone had left the Maori party and was setting out on his own, so far unchartered course.

In Palmerston North my role seems to involve chairing events and giving speeches as well as broadcasting on Kia Ora FM. So I had been in attendance in this kind of capacity at one or two events such as the time when Hone Harawira came to the Highbury Whanau Centre to talk in early 2011. I was asked to give the concluding speech and was struck by the situation that we all found ourselves in, especially Hone; alone and adrift and yet still fighting on. At that stage he did not have a party and he was looking for names. Mana was just one of a set of names that were canvassed at the meeting.

There is something of an invisible college where people without a formal connection but a shared interest in politics, 'radical politics' might be the appropriate phrase, get together regarding issues. I had been the MC for the most recent Hikoi on the foreshore and seabed when it came to Palmerston North en route to Wellington in 2010. The same or a similar set of people were involved in Mana as were involved in the organization of the Hikoi.

I next hooked up with the 'team', the college now starting to become visible, when I was asked to front the Mana selection meeting for Fred Timutimu, candidate for Te Tai Hauuru. This I was pleased to do as I had taught Fred at St Stephens as well as Te Ururoa, Shane, Hone, Rikirangi Gage and others. I should perhaps say that this group of people taught me more than I could ever have taught them!

A few days later I was on my way to Auckland and had stopped as I always do to buy a pie in Taihape. The bakery and pie shop opposite the Gretna Hotel is one of the best kept secrets in the country when it comes to pies. Then my car would not start. I opened the bonnet and looked up to see the Mana organizer for the district standing beside me. He said straight away, 'I want you to be the Mana candidate in Rangitikei'. I gamely struggled with the pie, the car and this proposition for a few moments and then said yes! 
The car promptly started and with that I was standing for Mana. Subject of course to the usual checks and approvals.

I was no longer watching things from a distance but I was on the field and about to start playing!

What follows is a week by week account of the campaign and then an analysis of the numbers.

It was Wednesday $21^{\text {st }}$ September when Fred Timutimu came to town and the meeting was held at Massey University. After the mihimihi Fred or Pererika spoke and then there was a round of korero in which I endorsed him as a candidate.

The next week having been to Auckland and back I sat in Taihape at a conference call and listened. An incredible amount of work had been done and the Mana, movement had been started and now had a hierarchy, policies and a direction.

By the end of September the Mana candidates for the Maori seats had been selected. Hone Harawira, Angeline Greensill, Annette Sykes, Pererika Timutimu, Tawhai McClutchie and Clinton Dearlove.

By now my network, if such it be called, for Rangitikei had been established. It was actually the network for Palmerston North with the addition of people in Taihape. And, interestingly, old mates from way back, people with whom I had worked in the mental health area in Wellington in the 1990s, colleagues from the bi-lingual unit at Wellington High School in the late eighties, fellow broadcasters, musicians and writers. They found me rather than being sought out by me. They just showed up out of the blue. Go figure.

I was also by now developing my own campaign and coming to terms with Mana policy most of which I liked a lot. There was the transaction tax promoted by Hone Harawira as the Hone Heke tax. There was the removal of GST. Then there was 'Feed the kids.' A great policy on housing calling for a warrant of fitness on houses. And there was a sense of purpose uniting the different bits of policy that took people back to the thirties, to the welfare state. In a Press Release of 
November $23^{\text {rd }} 2011$ Hone Harawira made the connection to the 1930 s very clear.

I campaigned on an idea of 'the lost'. This involved 'lost communities' the poor people living on the outskirts of places like Marton or any small town in the Rangitikei and 'the lost state', the set up that Mickey Savage had given us in the 1930s that had been taken away, bit by bit, by governments since then.

There was, I thought, a good fusion of the traditional and the post Treaty ideas of sovereignty with quite a switched on social and economic platform. For me, a person who had organized for the Labour Party and stood as a Labour candidate in 1987 only to watch a meltdown of purpose in the party after Douglas and Lange did what they did, the Mana movement was doing what Labour should have done.

\section{The Campaign and Election}

In early October I worked with my little campaign committee on a budget for the duration of the campaign in the Rangitikei. It may have all been cobbled together in a hurry but it seemed to work as far as it went.

In early October there had been a candidates' meeting at Waipapa marae at Auckland University. This was very well organized and went well. Again the invisible college started to manifest itself sometimes with voices and faces from the past. It was great to catch up with ex- students from Waikato and people like Peter Verschaffelt who I had not seen or heard since I was last a candidate for the Labour Party in the 1987 election. Good people and a good event.

On Saturday $15^{\text {th }}$ there was a meeting of the Central Region at Kawiu marae in Levin. Again I was really impressed with the commitment shown.

By the 24th I had designed a pamphlet. Generally there was not time or resource to have much in the way of 
pamphlets and billboards so that side of things was not a major feature of my campaign.

On October 29th I did a tour of the electorate going as far north as Taumarunui. Rangitikei is one of the longest electorates outside of the Maori electorates.

By this time I had a well- established press release in train. I would try to get one press release done every week day. I was amazed at how far they went and in one case the controversy that was caused. My Mana press releases made the Dubai Times and UK news. I found writing press releases to be a great intellectual stimulation and after the campaign I really missed doing this work. You really had to watch the political situation in the country and be alert. And not make gaffes.

At the outset of the campaign, trying to make ground too quickly I suppose, I did make a gaffe. While in the north of the electorate I had released a press statement about the Manawatu river in the south. This wrongly said in passing that my opponent, the National candidate Ian McKelvie, was the mayor of Horizons. With my mind elsewhere and not yet with a proper system of checking my press releases it was too late to retrieve my mistake before it went out on the net. Of course I promptly apologized and changed the press release and thought no more of it. People make this kind of mistake I figured and I had a lot of mayors, local bodies, rabbit boards and the like to consider in the Rangitikei electorate. But the Manawatu Standard was particularly unforgiving even bringing it up later when I apologized in public to Ian at a candidates meeting in Feilding.

And that, I think was the extent of the downside in my standing for Mana. A gaffe is a gaffe and one should learn and get on with it. Otherwise though the campaign was scandal free at my end as it was for the Mana movement at large.

By now though I had learned what I was good at- press releases and radio. I was regularly featuring on Waatea in Auckland in Maori. 
My Press Releases were like the following;

Press Release 14.11.11

Dr Peter Cleave, Mana, Rangitikei today took exception to the comments made by John Banks, Act candidate for Epsom currently circulating on the internet. Banks talks about Maori and Polynesian people on the dole at home watching pornography and planning burglaries.

'Why do we have to put up with this sort of nonsense?' asked Dr Cleave in an internet posting today. 'This is outrageous behaviour. Not only is the New Zealand public having to watch an abuse of MMP as they are seeing with Act and National in Epsom with the patently false standing of a National candidate there, we have a former Mayor of Auckland making an awful spectacle of himself.'

Dr Cleave wondered why this kind of comment was not being censured by the Race Relations Office.

'Banks would not get away with this in most countries,' he said. 'Why are we putting up with this kind of silliness here?'

\section{Looks like MMP but works like racism}

Tuesday, 15 November 2011,

\section{0:37 am}

\section{Press Release: Mana Party}

Looks like MMP but works like racism

'It looks like MMP but it works like racism,' said Dr Peter Cleave, Mana, Rangitikei after a candidates meeting in Feilding tonight in reference to John Key's 'cup of tea' with John Banks in Epsom.

'Here you have a leader of a small party, Don Brash of Act, who rails about race based funding and has done so since his Orewa speeches when he was in the National Party,' said Dr Cleave.

'There you have a new member of Act, John Banks who echoes his leader with the twist that Polynesians and Maoris are living off benefits in South Auckland, laying about watching pornography and planning burglaries. And John Key needs these people in 
Parliament to make his numbers secure. So he sits down with them and cuts a deal where his party goes soft in Epsom so that Act has a better chance of winning the seat. It looks like MMP but it works like racism. Banks and Brash probably will get to be in government, taking their race ideas that have effectively been endorsed by National with them. MMP should stay but we have to make modifications so that this kind of thing does not happen in Aotearoa- New Zealand.'

Dr Cleave said that arrangements like this made New Zealand an international laughing stock.

'A head of state sitting down with a small group of nutty right wingers using race as campaign tool? This is ridiculous.'

Dr Cleave was looking ahead to taking the Mana campaign for Rangitikei further north, to Kakahi in the King Country, this week.

Sometimes I would call Peter Verschaffelt and listen to his analysis and I found that very helpful.

All parties have friends and enemies. I made a point of attacking ACT and occasionally National and that seemed to work for me. Attacking other groups like Labour and the Maori Party may have worked for some candidates but it was not something I could see a lot of mileage in. People from those parties and the Greens should have been our friends in Mana but this was not always the case. Later I talk about this kind of thing with regard to Mana strategies in the future.

Also around this time with a few weeks to go to the election I thought a lot about the Mana movement and what it stood for. So far as I could see there were three basic parts to it. The first was a traditional idea of mana coming from time past. This is mana before the coming of Cook and enduring to the present day. The second is to do with the differentiation from Cook and company and particularly things that flowed from the Treaty of Waitangi, through the Maori seats and on into Te Puni Kokiri and other parts of state designated as Maori sectors. 
One could go all the way back to interchanges between Governor Grey and Wiremu Tamihana and discussion of a prestige apart, a mana motuhake, in the 1850s and 1860s.

Given that Hone Harawira was the leader of the party and given his Ngapuhi and northern connections then this second aspect, mana under the Treaty of Waitangi especially te tino rangatiratanga, was always going to be the main strand of the Mana movement in 2011. But one could go back to earlier versions of the Mana movement, particularly that of Eva Rickard in the 1970s and 1980s and find that the movement might relate to traditional ideas as much as matters since 1840. I was fortunate enough to have been in the Waikato at that time and went to several meetings at which Eva spoke including hui in Raglan where her philosophy was extensively discussed.

The third feature of Mana, the trade union connection, had been there before in Matiu Rata's Mana Motuhake Party but in 2011 it was a major part with Matt McCarten and his Unite Union people figuring largely in the party hierarchy as well as employees of Unite like John Minto being candidates and others being organisers. Matt McCarten was the original chairperson of the Mana movement after Hone and others had got the party organized. Annette Sykes became the chairperson after the election.

At the same time Unite did not, I think, formally back Mana.

The union connection might itself be better described as a movement or part of such, a movement that ran on to Occupy and to sites on the net and elsewhere.

So standing for Mana entailed a lot. A lot of fellow travellers, some who may not have been used to travelling together. My daughter Esme, a second year student at Victoria helped me with work on the internet and a lot of her friends seemed interested in Mana.

The Alliance and its history also had an effect on the Mana movement of 2011. Key organisers in Mana came from the 
Alliance and Matt McCarten himself drew on that source. 'Remember Alamein Koopu', was a refrain spoken to me several times and after my gaffe I took the idea of a person being hounded by the press seriously.

The campaign wore on and in the last three weeks I really started to enjoy it. My press releases were flowing and some like the ones on John Banks in Epsom were being repeated by the Mana machine, public meetings such as one at Rongotea school were lively and I had a great team around me.

Before we could draw breath it was election day. What a shock to the system! Hone got in and that was great and there were some strong results for Mana in the Maori seats. In the general seats there was a brick wall that did not allow any candidate to crack 1000 votes. It was a real lock out.

How to consider the results? The main results in terms of numbers came from the Maori seats. There was a clear NorthSouth distinction in the Maori seats. Hone in the north got most votes and Clinton in the south got least. In between there were variations but by and large as you come down the country the Mana votes decrease in the Maori seats.

In terms of votes the Maori seats offered the major results.

In the general electorates Mana got the scraps. These might be called the minor results although there are crossovers and connections suggested below to the Maori seats. It was a clear lock out or a shut out of the Mana candidates in the general seats. Later I will explore why that was but before that it is worth, I think, an analysis of the voter figures, however small, in the general seats as well as an analysis of the more substantial figures in the Maori seats.

The North South distinction in the Maori seats is not so evident in the general seats and this is shown in the party vote. The upshot of this is that attention should be paid to places like Dunedin North and Wellington Central where the party vote is higher than in other electorates despite there not being a candidate. 
The striking thing in a big picture analysis is the range in the Mana vote. There is Hone with a lot of votes and then there the seats with less than 100 votes. Mana is not a party with a consistent appeal across electorates. Another new kid on the block, the Conservatives seemed to poll more consistently across electorates but they do not have a charismatic leader with the force that Hone has to actually take out a seat. Somehow Winston Peters managed to project his personal charisma and get a consistently high poll in electorates other than his own with little known candidates as well as with the party vote. But Mana has a range and that is worth analyzing as we go forward. The range could ultimately be its strength.

The votes may be grouped in various ways and I have chosen the following five groups;

$1 \quad 0-100$ votes

$2 \quad 100-500$ votes

3 500-2000 votes

$4 \quad 2000-7500$ votes

5 Over 7500 votes

These divisions seemed to me to be useful in terms of the strategies that Mana might employ across the range of electorates. It might have been possible to have divisions from $0-500,500-7500$ and over 7500 but I think it is more precise to deal with the wide range found in the Mana vote across the country in the way suggested above. Getting past 100 votes is an old maxim but a good one. You need to go past your family and friends. Getting past 500 votes shows you have a network. Going past 2000 indicates a good profile and some support for your party as well as a network. Going past 2000 would indicate a network bolstered by the support of a Union or Church. Going past 7500 shows that you are a serious candidate in pretty well all respects and that your party is well regarded and has credibility. 
These divisions may be the basis for cluster groups.

The clustering of candidates by the candidate vote helps us see who is attracting votes and where.

The clustering of electorates by party votes helps us see where there are building blocks for Mana to add candidates, pamphlets, billboards, meetings and other things. For example the Party Vote Clusters below show that Auckland Central and Wellington Central both got fairly large party votes in the general seats. We need to stress these next time. These electorates now become goals for candidates. For example, having stood for Rangitikei, an electorate in the 0-100 party vote bracket my goal for the next election might be, say, Wellington Central, Auckland Central or Whangarei, these electorates being in the party vote bracket of 200-500.

The party vote clusters also show us where we should be standing candidates. In the general seats Mana did not stand candidates in Auckland Central, Wellington Central or Whangarei and these are all in the better General seat party vote clusters.

We could also form cluster groups in policy areas. Those candidates interested in economics, the environment or any other policy area might form a cluster group where they share information, have discussions on the net and so forth.

Another cluster might be formed around people who are interested and effective in media promotion. In my case I had a number of press releases widely circulated on the net and I would be happy to be included in such a group.

Another cluster might be formed from those interested in community networking. 
Cluster Set One

Candidates by vote

$1-100$

O’Dea, Epsom 66

Paul, Napier 86

Gardiner Tauranga 90

What strategies do these candidates have to employ to get over 100 votes?

How can Mana help these candidates get over 100 votes?

What is the candidate and party competition in this bracket?

100-500

Cleave Rangitikei 110

Tumai, Barry Maungakiekie 145

Stevens, Sharon Bay of Plenty 251

Irwin, Val East Coast 256

Reedy, Keriana Taupo 266

Bradford Waitakere 320

Cooper Richard Manurewa 387

Papali'i James Mangere 422

Minto Manukau East 461

What strategies do these candidates have to employ to get over 500 votes?

How can Mana help these candidates get over 500 votes?

What is the candidate and party competition in this bracket?

$500-2000$

Rogers, Grant Rotorua 510

Herewini Northland 611 
Clinton Dearlove, Tai Tonga1360

Frederick Timutimu Te Tai Hauauru 1513

What strategies do these candidates have to employ to get over 2000 votes?

How can Mana help these candidates get over 2000 votes?

What is the candidate and party competition in this bracket?

This cluster might show the need to put candidates from the Maori seats with candidates from the general seats at least for brainstorming and problem solving activities.

2000-7500

Tawhai McClutchie Ikaroa Rawhiti 2484

Kereama Pene Tamaki Makau Rau 2827

Angeline Greensill Hauraki Waikato 3816

Annette Sykes 5768

What strategies do these candidates have to employ to get over 7500 votes?

How can Mana help these candidates get over 7500 votes?

7500 and over

Hone Harawira 8121

What does Hone, as the most successful Mana candidate do to uplift other candidates next time and what do they do to further uplift him?

The 500-2000 set, the 2000-7500 set and the 7500 and over set might involve different strategies in each cluster. 
Certainly Hone's strategy in the over 7500 group could well be different, say, to those in the 500-2000 set.

The cluster groups might help to design and then answer questionnaires appropriate to their group. Such questionnaires might be based around the notion of how candidates can move from their bracket to the next one. A questionnaire might have ten sections asking the candidate how she or he intends to advance to the next voter group. The questions at the end of each section above might be starters for such questionnaires.

From these questionnaires specific strategies for candidates could emerge. For example to move from the 100500 to the 500-2000 bracket community networking might be a good strategy. To move from the $500-2000$ bracket to the 2000-7500 bracket more public meetings might be involved and to move from the 2000-7500 bracket to the over 7500 bracket more radio and television might be required. Each cluster group would be given a questionnaire specific to their goals in moving up to a greater level of votes.

The strategies above are offered as examples but it might be important for Mana to set out some strategies for each cluster and then to build a comprehensive party wide policy around the desired strategies. Alternatively candidates could be asked to conform to a set of guidelines, those guidelines being slightly different for each group. To return to a point made above the range of voter numbers could be a weakness but handled properly with appropriate bridging between voter groups the range could be a real strength.

Individual strengths might be targeted. For example if someone is good at community networking then their strengths can be employed in focus groups to help other candidates. As suggested above this might be particularly important in the 100-500 voter group or the 500-2000 group.

If community networks are well set up in a given area and a candidate with good media skills is added to that then there 
might be a way forward in the $500-2000$ or the $2000-7500$ sets of seats.

Another function of ongoing cluster groups is to be ready for by-elections. For example, the possibility of a by-election in Waitakere. This did not happen but if it had then the following might have been considered;

1 our last effort. The candidate was in the 100-500 area as was the party vote in Waitakere

2 all Mana candidates in the 100-500 voter group throughout the country at the 2011 election might be alerted before the selection process as being contenders for the Mana candidacy. So could people from the 500-2000 cluster.

This brings us to the List as there would possibly be a process involving the List in candidate selection for a byelection.

Regarding resources and List placing there may be a bit for Mana to learn. Those higher on the list often get more resources. At Number Twenty on the list Ngawai Herewini got the most votes while others in the top five or ten on the list came in at lower points. List and party resources are related in that Mana, like other parties, will give more advertising and attention to people in the top five or ten positions on the List.

You can look at it in various ways but there might be merit in the suggestion that once over one hundred votes there is a little momentum, once over 500 a little more and to move a candidate from 500 votes to 1000 might not be as difficult as going from zero to 100 given more attention from the media and more resources with pamphlets and billboards and so forth. So we need to identify who is likely to come in with votes, at what level they are likely to come in and then to put them on the list accordingly and fund them appropriately within our resources. Voters are looking at the parties and assessing them on their lists as well.

If we take the $100-500$ vote bracket the people that we find in that bracket and their List placings are; 
Cleave Rangitikei 110 Party Vote 62 No 11 on list

Tumai, Barry Maungakiekie 145 Party Vote 140 No 19 on the list

Stevens, Sharon Bay of Plenty 251 Party vote 91 No 13 (?) on list

Irwin, Val East Coast 256 Party Vote 224 No 12 on list

Reedy, Keriana Taupo 266 Party Vote 140 No 14 on list

Bradford Waitakere 320 Party Vote 174 No 4 on list

Cooper Richard Manurewa 387 Party Vote 215 No 10 on the list

Papali'i James Mangere 422 Party Vote 252 No 5 on the list

Minto Manukau East 461 Party Vote 253 No 3 on list

In the 500 plus bracket there is

Rogers, Grant 510 Party Vote 327 No 17 on list

Herewini Northland 611 Party Vote 420 No 20 on list

In the 2000 plus bracket there is Hone and Annette at numbers one and two on the list.

The Herewini example shows an exact opposite of what should be. Ngawai Herewini is the top polling candidate in the General seats but the lowest placed on the list. So the way we select people for the list based on votes, the main currency of politics, might need to be looked at. There are other factors obviously and I touch on these in the concluding comments.

\section{List Two Party Vote Clusters}

$0-100$

Bay of Plenty Botany Christchurch East Clutha Southland Coromandel East Coast Bays Epsom Hamilton East Dunedin South Helensville Hunua Ilam Invercargill Kaikoura Mt Roskill Napier Nelson New Plymouth North Shore Ohariu Otaki Pakuranga Palmerston North Rangitata Rimutaka Rangitikei Rodney Tamaki Taranaki- King Country Tauranga Waikato 
Waimakariri Wairarapa Waitaki West Coast Tasman Whanganui Wigram

100-200

Christchurch Central Dunedin NorthHamilton West Hutt South Mana Maungakiekie Mt Albert New Lynn Northcote Rongotai Papakura Port Hills

Selwyn Taupo Te Atatu Tukituki Waitakere

200-500

Auckland Central East Coast Mangere Manukau East Manurewa Northland

Rotorua Wellington Central Whangarei

$500-2000$

Te Tai Hauauru Te Tai Tonga Ikaroa Rawhiti

2000-5000

Hauraki WaikatoTamaki Makau Rau Te Tai Tokerau Waiariki

The obvious growth point to me in the sets above is the 200-500 set of electorates. Voters show more than a passing interest in these electorates and organization and resources might well be dedicated to them. If they could each be taken to 2000 , the upper limit of the next category, there is 18,000 votes there.

\section{Other Observations}

There are several points made below. Some of these are my own thoughts and some are responses to other reviews that I have seen and comments that I have heard.

Mana is a movement of the left. Maori did vote left in the Maori seats. For example in Te Tai Tonga there was a shift to Labour in both party and candidate vote. The shift was similar 
in the party vote in Tamaki Makau Rau and the trend appears elsewhere. Maori went left in many cases but did not, or not always, go to Mana

There is a clear North -South tendency in the voting in the Maori seats. Hone Harawira did well on party and candidate fronts in Te Tai Tokerau. By contrast Clinton Dearlove in Te Tai Tonga worked really hard and well with a lower result. Tawhai, Angeline and Annette are between those points as is Fred. Other factors came into play. A candidate with a strong Labour whakapapa won Te Tai Tonga.

Ngawai Herewini did better than other candidates in party and candidate vote in the General Seat of Northland and the General seats show something of the same North -South trend although the party vote in the South Island is sometimes quite high- in Dunedin North for example- and there is more variation across the country.

One review suggests that we did better in seats where Mana stood a candidate. I'm not sure that is always true. For example in Dunedin North with no candidate Mana got 150 votes. That compares favourably to several electorates where Mana had candidates and it beat the Maori Party vote by nearly a third, the Maori Party coming in at 107 there. The Dunedin North party vote for Mana compares favourably with the party vote in the electorates of candidates at high positions on the Mana list- 150 in Dunedin North to 118 in Waitakere or 187 in Manukau East for example. Wellington Central, also without a candidate, got a party vote of 175 . So standing a candidate, even one with a high list placing and resources may not always help.

Networks are another issue. Given the North-South distinction in the voting in the Maori seats it may be that kin networks function strongly for Mana. The vote might show the influence of kin networks involving Harawira in the north and Tirikatene in the south. We may have problems with networks of workers though. In my case I put a great deal of time into the CMC Lockout and that involved going to the picket line 
more often, I think, than any other candidate and encouraging Te Karere to come and do a long segment that headlined in the week before the election. But there was no associated spike in the polling booths for Mana, party or candidate wise in Feilding or Marton where the workers live. So I am asking myself what I have to do to encourage voting by networks of workers. I think similar questions might be asked across the board in the general seats for Mana candidates.

Those of us who stood in the general seats have to ask now why we were stonewalled, why no-one cracked 1000 votes and why the numbers are so low generally. Independents, Legalise Cannabis and, occasionally the Alliance did better in places. Our own credibility might be the starting point. How do we increase our own credibility as individual candidates between now and the next election?

Strengthening the range of the Mana movement in the eyes of the public might be another. The first point about range might be candidates. At present we have Hone who is a charismatic leader and stands, as it were, for the Mana movement. How do we develop other charismatic personalities?

The strategy going into the campaign seemed to involve a quartet; Hone and Annette and John and Sue. The Top Four approach may or may not be the way to go next time and the following questions might be posed now;

1 who got votes? This is dealt with above and Hone and Annette did get votes but John and Sue did not or at least not to any degree that set them apart from the rank and file on the list.

2 who got media? This is important because in a regular campaign it is the eighteen months before an election and the grind of daily press releases that establishes political parties. Analysis would need to be carefully done but my impression is that Hone, Annette, Clinton, Sue and me got the kind of 
consistent media attention and range you need to drip feed the public about the credibility of a party.

3 who targeted the right enemies? This is an important question as going forward the temptation is to continue the practice of attacking the Maori Party that was in evidence in the last weeks of the campaign. I don't think this is a good idea. Personally I think a steady attack on John Key and National and John Banks and Act is the starting point for attack.

4 Who promoted the right policies?

If we can find policies that grow the vole in seats like Wellington Central, Auckland Central, Whangarei and Dunedin North then this will give us some depth in those areas. Should we be tweaking our policies to suit urban elites? If we are setting out baseline issues for the voters of the Tai Tokerau in hard pressed financial circumstances on the one hand and titillating urban elites on the other then more power to us. So long as the baseline policies are not altered-feeding the kids, making sure housing is safe and so on- then Mana might well proceed to grow in other places. The arts are one area that I thought about a lot during the campaign but I could not seem to get a decent Press Release together about that sort of thing. None of the other parties seem particularly strong in that area though...

From one person I got the following message;

'The issue of leadership charisma in this election is one worth considering:

National - Key was practically the only public face of the party. The 'charismatic' leader was what strategists believed would work in terms of making the party appealing

Labour - Goff's absence from the billboards was an acknowledgement that his lack of charisma was a factor. 
However, without a 'face' for the party, it was always going to be hard to appeal to voters

Greens - two charismatic leaders who featured prominently in the campaign

Maori - two leaders who were less than charismatic especially Turia, who looked fatigued. Maybe this was a factor in voter support

\section{Mana}

Mana perhaps ought to have stuck to the successful approach of utilising a charismatic leader and excluding the appearance of other candidates (as National did). However, what it did was to highlight Bradford and Minto, as well as dilute the Maori message of the partly by tacking on socialist economic policies. The lesson here seems to be if you have a charismatic leader, stick with him/her, and base all publicity around the leader.'

I disagree with the idea that you can't put Left and Maori together, that socialist economic policies diluted the Maori message.

There may be merit in the 'one face' argument though and we might ask the following questions;

1 Did we have too many faces?

2 Did we do enough with Hone's face, his image?

3 Did we have the right faces?

Then there is the matter as to what is a Maori issue. Do we really know what issues Maori are interested in? If we did then surely the voter turnout would have been higher. I think we need to do more polling of Maori. This could be street poll or focus group work on a kanohi ki te kanohi basis.

One review says; Being both left \& Maori-focused creates a double hurdle for Mana... Rather than a 'double hurdle' I think 
it creates a double opportunity. We have to figure out how to maximize those opportunities now. For example if we take Wellington Central and Dunedin North where Mana party votes are high without a candidate then these are areas that we need to target with candidates very soon so far as I can see. They are growth points, doorways for development. What are the left issues and what are the Maori issues in those electorates?

What are we doing with social media? In my case I got a reasonable response on the net with press releases being picked up by media groups but this did not translate into party or candidate votes in my electorate although there may have been a general diffusion of the releases that helped the overall effort. I think we need to take a hard look at what we are doing with social media and develop strategies that clearly relate to getting votes. I see my own work in this area as being too tangential. For example I went to the Occupy site in Auckland recently. People there who had campaigned in Epsom commented favourably on press releases I had made during the campaign regarding John Banks. One or two people gave me the idea that my press releases influenced them to vote Mana in Auckland but all that was a long way from Rangitikei.

One review asks; How can we lessen the burden on Hone as the one MP? We might best do this by having a system of spokespersons in place to provide the media with regular feeds and the points made earlier about policy cluster groups might apply here. We might also find ways to be in and around Parliament. The Mana machine needs to be well structured and organized with good financial and IT systems. We need to be working towards the next election by defining issues, working out the networks we need to use and polling so that Hone can lead on an informed basis.

What kind of data do we need to go forward? I think we need information banks better than other parties have on things like meals in schools so that Hone is superbly informed. 
Hone already has the inside running on a number of issues like smoking. To maintain and increase that edge he will need a regular supply of error- free and up to date information.

Where are we now and how do we get from point to point?

\section{General Seats}

The average candidate vote in the general electorates was 259. So we are over half way to the 500 vote mark as an average. How do we get from half way to all the way there? Our goal might be to double the average candidate vote in the next three years.

\section{Maori Seats}

In the Maori seats there are some important trends. The North-south distinction is noted above. So is the swing to Labour, especially in the south. The Party vote for Mana is 4131 in Te Tai Tokerau, 2,661 in Waiariki and 2,128 in Tamaki Makau Rau. How do the other seats get over the 4000 vote mark and look like the Tai Tokerau figures? How could Mana go over 5000 party votes in all Maori seats?

\section{Closing comments}

So standing for Mana had taken me from a meeting at the Highbury Whanau Centre and a feeling of loneliness and estrangement as I listened to and interacted with Hone Harawira immediately after he left the Maori Party to a chance meeting outside the pie shop in Taihape, to the elation that comes when you see a Press Release you have written being well read and circulated and then to a brick wall result. This was the kind of failure that comes once in a while in life and definitely should not come too often! When formerly I had stood for Labour in 1987 it had felt right to me that I should run the National Party candidate close and I really did not think that much about it. It had been a loss and that was not good, but I had turned the seat into a marginal one, and scored in the thousands while the independents and the like 
were around the $100-500$ vote area. But to get mere 100 or 110 votes as I did standing for Mana in 2012 was truly ignominious. I had gone from being a mainstream contender in 1987 to being an eccentric in 2012 .

And yet it was great fun. Something about the policies of Mana, cobbled together in a hurry as they were and patched up as we went along was very attractive and I felt that standing for Mana had been a healthy thing to do. 